\title{
The Growing Phenomenon of Private Tutoring: Does It Deepen Human Capital, Widen Inequalities, or Waste Resources?
}

Hai-Anh Dang • F. Halsey Rogers

Does private tutoring increase parental choice and improve student achievement, or does it exacerbate social inequalities and impose heavy costs on households, possibly without improving student outcomes? Private tutoring is now a major component of the education sector in many developing countries, yet education policy too seldom acknowledges or makes use of it. This survey of the literature examines the extent of private tutoring, identifies the factors that explain its growth, and analyzes its cost-effectiveness in improving student academic performance. It also presents a framework for assessing the efficiency and equity effects of tutoring. The results suggest that even taking equity concerns into account, tutoring can raise the effectiveness of the education system under certain reasonable assumptions. Guidance is offered for attacking corruption and other problems that diminish the benefits of private tutoring. JEL codes: I21, I22, D10.

Developing country policymakers recognize that education is a key determinant of individual productivity and economywide growth. But their sector diagnoses and policy attention have focused on public schools. Much less attention has been paid to the private school sector, and policy discussion rarely mentions what is emerging as a third important education sector: the private tutoring industry.

In many countries, private tutoring has arisen as a parallel education sector that provides supplementary instruction to students enrolled in the public school system. Substantial private tutoring industries can be found in countries as economically and geographically diverse as Cambodia, the Arab Republic of Egypt, Japan, Kenya, Morocco, Romania, Singapore, the United States, and the United Kingdom.

This survey cites evidence on the prevalence of tutoring in 23 developing and developed countries. In almost all of them, 25-90 percent of students at certain levels of education are receiving or recently received private tutoring. In some

(C) The Author 2008. Published by Oxford University Press on behalf of the International Bank for Reconstruction and Development / THE WORLD BANK. All rights reserved. For permissions, please e-mail: journals.permissions@oxfordjournals.org doi;10.1093/wbro/lkn004 Advance Access publication April 18, 2008 
countries, such as the Republic of Korea (hereafter Korea) and Turkey, spending by households on private tutoring now rivals public sector education expenditures.

Private tutoring has elicited mixed responses from policymakers. In some countries it is ignored; in others it is actively controlled and regulated. Private tutoring has been banned at various times in Cambodia, Korea, Mauritius, and Myanmar (Bray 1999a), out of concern that it exacerbates social inequalities, disrupts the public education system, and fails to increase academic performance or build human capital.

Policymakers need evidence to formulate good policy toward private tutoring. What factors (micro and macro) drive the demand for private tutoring? Do only rich households use private tutoring? How is private tutoring different from private or public education? What effects does private tutoring have on students' academic performance? Is private tutoring a cost-effective form of education? Does the evidence suggest that increased use of private tutoring is a welcome development or one governments should discourage?

Policymakers may find it preferable to formulate views on these questions before private tutoring becomes even more entrenched. Once it emerges as a major industry - especially if wealthier parents see it providing competitive advantages to their children - it will likely be harder for governments to adjust policy in ways that threaten vested interests.

This article reviews what is known about the determinants and effects of private tutoring and analyzes the equity and efficiency issues, with a focus on developing countries. It begins by establishing the economic importance of private tutoring in much of the developed and developing world. It then provides a simple framework of the supply of and demand for education, which guides the discussion of equity and efficiency issues. The next sections review the determinants of private tutoring, from both a micro and a macro perspective, and the effects of tutoring on student achievement, paying special attention to the statistical problems associated with identifying these effects and to recent studies that have addressing these problems. The last section uses these results and the theoretical framework to discuss the efficiency and equity implications of private tutoring, explore their implications for policy toward tutoring, and identify areas that may warrant more research.

\section{The Widespread Phenomenon of Private Tutoring}

Private tutoring is defined here as fee-based tutoring that provides supplementary instruction to children in academic subjects they study in the mainstream education system. ${ }^{1}$ Because the literature focuses primarily on tutoring for 
children or adolescents paid for by their households, tutoring can generally be considered a form of private education. However, the definition is broad enough to cover special tutoring programs financed by other sources, including the government (for example, remedial education programs).

There are good reasons why a private supplementary tutoring sector might emerge to complement the public and private schooling systems. Private tutoring can provide more individualized instruction than is possible in public schools, using a more flexible delivery mechanism. The private tutoring industry is also differentiated from the private school sector in that its existence depends on the mainstream education system; it does not stand alone as an independent educational activity. This aspect of private tutoring helps explain why it has been referred to as "shadow education" (Bray 1999a). Private tutoring is also less formal and more flexible than private schooling: it can include not only one-toone tutoring but also group classes, it can be provided not only by full-time tutors and teachers but also by university students, retired teachers, university professors, and community members (Russell 1997). Because it supplements rather than replaces the public sector, the combination of public schooling and private tutoring is also more affordable for many households than private education would be.

Japan has been a pioneer in the provision of this type of supplementary education. Private tutoring has long been a huge commercial industry in Japan, with annual revenues reaching an estimated $\$ 14$ billion by the mid-1990s. Nine private tutoring schools were already listed on the Japanese stock exchange at that time, and the tutoring sector had become a "crucial component of Japanese education" (Russell 1997). Many Japanese students enroll in intensive tutoring programs during school vacations, including the important New Year's holiday. To stimulate school spirit, several private tutoring schools ( juku) have had their students wear white headbands similar to those once worn in battle by samurai warriors (Rohlen 1980). About 30 percent of university students spend additional years after high school graduation cramming for their university entrance examinations, often in specialized private tutoring classes. At the top-ranked schools, more than 60 percent of students may have spent time after high school preparing for these exams (Ono 2007).

Japan is not alone in supporting a large and vibrant private tutoring industry. Tutoring is now widespread in many parts of the world, including developing countries (appendix table A.1).

Certain patterns are clear. First, while the incidence of tutoring appears highest in East Asia, private tutoring is an important phenomenon in countries of different sizes, levels of economic development, political institutions, and locations. In some cases, spending on private tutoring approaches the level of spending on the formal public school system. In Korea, for example, households 
spent 2.9 percent of GDP on private tutoring in 1998 - almost as much the 3.4 percent of GDP the public sector allocates to education (Kim and Lee 2004). In Turkey households spend more than 1.4 percent of GDP on private tutoring-close to the 2.0 percent the country spends on public education (Tansel and Bircan 2006).

Second, private tutoring is an important phenomenon not only for upper-secondary students preparing for university exams but also for students at the primary and lower-secondary levels. In some countries, such as Japan, it is widespread among upper-secondary graduates as well.

Third, the private tutoring industry appears to be growing in many countries, both in absolute terms and relative to the formal education sector. The percentage of students receiving tutoring is rising in Kenya and Mauritius, and the number of private tutoring firms is rising in Canada and Turkey (see table A.1). ${ }^{2}$ Evidence on tutoring expenditures also supports the notion that the sector is growing. In Korea, for example, household spending as a share of GDP on private tutoring rose continuously, from 0.7 percent of GDP in 1977 to 1.2 percent in 1990 and 2.9 percent in 1998 (Kim and Lee 2004). Finally, anecdotal reports suggest that private tutoring is expanding in other countries as well. In both low-income countries (such as Vietnam; Dang 2007a) and high-income countries (such as the United States; Fuchs 2002; Borja 2005), some households in some areas have begun sending their children to private tutoring to give them an edge as early as preschool.

\section{A Framework of Private Tutoring Supply and Demand}

A simple graphical framework based on the standard microeconomic theory of supply and demand is useful in interpreting the private tutoring phenomenon. Consider the supply of and demand for education by a typical household where private tutoring is available (figure 1). The supply of education is represented by the supply curves $S_{0}$ for private education, $S_{1}$ for public education, and $S_{2}$ for public education with private tutoring. $S_{1}$ is different from $S_{2}$ in that while the two curves share a common solid upward-sloping part ending at point A, $S_{1}$ includes the solid vertical line rising from point A while $S_{2}$ includes a dashed diagonal line starting from point A. (It is possible to think about the dashed line as the supply curve for private tutoring alone.)

The rationale for the vertical part of $S_{1}$ (starting at point A) is that regardless of consumer demand, after a certain point public schools reach their capacity limit, preventing them from offering as much education-in terms of both quantity and quality - as parents or students want (that is, supply becomes perfectly inelastic). ${ }^{3}$ By contrast, the dashed portion of the supply curve $S_{2}$ (public 
Figure 1. Education Supply and Demand with Private Tutoring

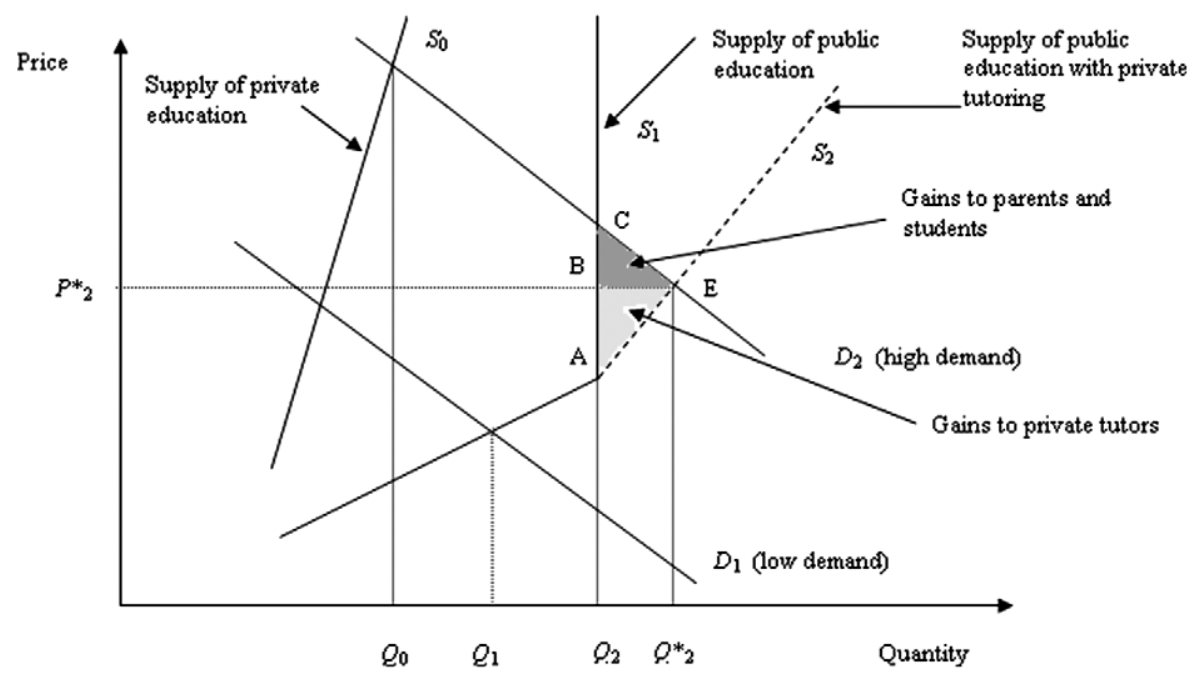

education with private tutoring) is flatter than the vertical part of $S_{1}$, indicating the ability of private tutoring to meet the demand for education where the public education system cannot. This portion of $S_{2}$ is steeper than the lower part of $S_{1}$, reflecting the assumption that even where public school is not free, private tutoring usually costs the household more than public schooling does. ${ }^{4}$

Even if tuition is not charged, a household incurs certain costs in sending a child to school (for example, school-related fees, the opportunity cost of the child not working). Household demand for education is represented by the demand curve $D_{1}$ (low demand) or $D_{2}$ (high demand). The demand curve $D_{2}$ represents a household that is assumed to have higher income, stronger education preferences, higher expectations about future returns, or some combination of these variables relative to a household whose demand is given by $D_{1}$. (Other factors, such as the price of substitute goods and the number of buyers in the market, also shift the demand curve. The focus here is strictly on the factors cited above.)

The amount of education the household consumes is represented by the amount on the horizontal axis corresponding to the point where the supply and demand curves meet. If the representative household's demand for education is represented by the demand curve $D_{2}$, the amount of public education the household consumes is $Q_{2}$. In the presence of private tutoring the same household can consume a larger amount of education $\left(Q_{2}^{*}\right)$, because the supply curve is no longer constrained by the vertical segment rising at point A. Were the household instead to enroll all their children in private school, the consumed amount of education would be lower, at $Q_{0}$. 
This "standard framework" underlies the discussion of the determinants and welfare consequences of tutoring. It incorporates certain assumptions that may not always be valid. One such assumption is that the market for private tutoring is competitive and that households are free to choose whether to purchase tutoring services. A second is that public schooling reaches a strict capacity constraint after a certain point, which is likely a better description of the short run than the long run. The last section of this article explores how relaxing these assumptions affects the analytical and policy conclusions.

\section{Drivers of Private Tutoring}

To understand the equity and productivity effects of the large and growing private tutoring sector and design effective policies, it is essential to understand the micro and macro factors that create demand for tutoring. Factors at the micro level may include the characteristics of individuals, households, schools, and communities. Macro-level factors may include the share of public spending allocated to public education, the characteristics of the education system and labor market, and national cultural values. Together these factors determine the level and slope of the tutoring demand curve for society as a whole. This section presents the evidence from the literature on both sets of explanatory factors.

\section{Micro Factors}

Standard economic theory would suggest that certain factors increase household demand for education: households' income, preference for education, and expectations about the returns to education for their children. These factors explain the heterogeneity of demand across household types. Compared with households on demand curve $\mathrm{D}_{1}$, which consume no private tutoring given the supply curve $S_{2}$, households on demand curve $D_{2}$ consume $Q_{2}^{*}-Q_{2}$ of private tutoring.

Empirical research supports the theoretical prediction about which factors increase demand. Studies of Egypt (Assad and El-Badawy 2004), Japan (Stevenson and Baker 1992), Korea (Kim and Lee 2004), Turkey (Tansel and Bircan 2006), and Vietnam (Dang 2007b) are highlighted because they draw on nationally representative data. The private tutoring sector is also relatively prominent in all of these countries, which together capture some of the geographic variation in the phenomenon. (Buchmann 2002, Davies 2004, and Psacharopoulous and Papakonstantinou 2005 investigate the determinants of private tutoring using smaller data sets.)

The variables that most influence consumption of private tutoring in these studies are household income (household wealth in Egypt, household expenditure in Turkey and Vietnam); parental education; and urban location (table 1). 
Table 1. Leading Determinants of Private Tutoring in Selected Countries

\begin{tabular}{|c|c|c|c|c|c|c|}
\hline \multirow[b]{3}{*}{ Independent variable } & \multirow{3}{*}{$\begin{array}{c}\text { Egypt, Arab Rep. } \\
\text { of } \\
\text { Per child } \\
\text { expenditure on } \\
\text { private tutoring }\end{array}$} & \multirow{2}{*}{ Japan } & \multirow{2}{*}{$\begin{array}{l}\text { Republic of } \\
\text { Korea }^{a}\end{array}$} & \multirow{2}{*}{ Turkey $^{b}$} & \multicolumn{2}{|c|}{ Vietnam $^{c}$} \\
\hline & & & & & $\begin{array}{l}\text { Primary } \\
\text { students }\end{array}$ & $\begin{array}{c}\text { Lower-secondary } \\
\text { students }\end{array}$ \\
\hline & & $\begin{array}{c}\text { Participation } \\
\text { in after-school } \\
\text { private } \\
\text { tutoring }\end{array}$ & $\begin{array}{l}\text { Per child } \\
\text { expenditure } \\
\text { on private } \\
\text { tutoring }\end{array}$ & $\begin{array}{c}\text { Log of } \\
\text { household } \\
\text { expenditure } \\
\text { on private } \\
\text { tutoring }\end{array}$ & $\begin{array}{l}\text { Log of per child } \\
\text { expenditure on } \\
\text { private tutoring }\end{array}$ & $\begin{array}{l}\text { Log of per child } \\
\text { expenditure on } \\
\text { private tutoring }\end{array}$ \\
\hline $\begin{array}{l}\text { Household } \\
\text { income }\end{array}$ & Mixed results ${ }^{\mathrm{d}}$ & $* * *$ & $* * *$ & $* * *$ & $* * *$ & $* * *$ \\
\hline $\begin{array}{l}\text { Father's years of } \\
\text { schooling }\end{array}$ & $* *$ & $* * *$ & $* * *$ & $* *$ & Not significant & $*$ \\
\hline $\begin{array}{l}\text { Mother's years of } \\
\text { schooling }\end{array}$ & Not significant & $* * *$ & $* * *$ & $* * *$ & $*$ & Not significant \\
\hline Urban location & $* * *$ & $* * *$ & $* * *$ & $* * *$ & $*$ & Not significant \\
\hline $\begin{array}{l}\text { Number of } \\
\text { observations }\end{array}$ & 6,114 & 3,053 & 6,576 & 3,898 & 2,347 & 1,179 \\
\hline $\begin{array}{l}\text { Econometric } \\
\text { model }\end{array}$ & Tobit & Logit & Tobit & Tobit & Tobit & Tobit \\
\hline
\end{tabular}

*Significant at the 10 percent level; **significant at the 5 percent level; ***significant at the 1 percent level.

${ }^{\text {a }}$ Significance level of the urban variable is inferred from the strong significance levels for the dummy variables indicating living in high-density residential areas, living in Seoul, and living in metropolitan city or small or medium-size city.

${ }^{\mathrm{b}}$ Household income is the log of total household expenditure. Father's years of schooling are for household heads.

${ }^{\mathrm{c}}$ Household income is the $\log$ of household expenditure per capita.

${ }^{\mathrm{d}}$ Significance level of household income is inferred from that of dummy variables indicating households in different wealth quintiles, which range from insignificant to highly significant.

Source: Estimates are from the following: Egypt, Assaad and El-Badawy (2004); Japan, Stevenson and Baker (1992); Republic of Korea, Kim and Lee (2004); Turkey, Tansel and Bircan (2006); and Vietnam, Dang (2007b).

The last two variables arguably correspond to household preferences for education. These results are not unexpected, but they are surprisingly consistent across countries and fairly robust to the models used. ${ }^{5}$

Other factors that may matter across countries are grade level and household size. In Egypt students in diploma-granting grades spend more on private tutoring (Assad and El-Badawy 2004). In Vietnam the closer students are to the last grade in their current school level the more they spend on private tutoring (Dang 2007b). In Korea, Turkey, and Vietnam the number of children in the household is negatively correlated with private tutoring expenditures (Kim and Lee 2004; Tansel and Bircan 2006; Dang 2007b). Presumably, the grade-level pattern reflects the use of private tutoring to prepare for school-leaving examinations. The household-size effect hints at the much-studied tradeoff between quantity and 
quality (number of children and average child educational achievement; see, for example, Becker and Lewis 1973; Blake 1989). This variable is likely to be endogenous (see the next section), which may bias the estimates. Not all of these variables are used in all of the studies. It is thus not possible to investigate whether these patterns hold for all five countries or to draw firm conclusions from them.

Other variables that affect spending on private tutoring vary from country to country. This diversity of findings may reflect differences in the models or in the variables available in the data sets. It could also reflect country-level differences in tutoring patterns, perhaps as a result of differences in institutions, cultures, or relative prices.

Do students receive private tutoring for remedial or enrichment purposes? Are most students who receive tutoring performing at levels below or above their (conditionally) expected levels? Analyzing data from the 1995 Third International Mathematics and Science Study (TIMSS) in 41 countries Baker and others (2001) show that in three-fourths of these countries private tutoring is used significantly more often by low math achievers than by high achievers (controlling for family income, student, and community characteristics). They show that the probability of receiving private tutoring increases by 3.5 percent for each one-point decrease in TIMSS math scores in Denmark, Germany, and the United States.

The core explanatory factors common to all studies-income, parental education, urban location - echo those usually found to be important determinants of schooling attainment and performance in developing countries. In their study of 35 developing countries, for example, Filmer and Pritchett (1999) find that household wealth is strongly related to the educational attainment of children nearly everywhere. The multicountry analysis by Hanushek and Luque (2003) finds that on average parental education and family asset ownership are as important in explaining children's test scores in developing countries as they are in developed countries. Tansel $(1997,1998)$ finds that parental education, household consumption, and urban location are associated with higher educational attainment in Côte d'Ivoire, Ghana, and Turkey.

\section{Macro Factors}

Several factors are likely drivers of the demand for private tutoring at the macro level. First, the transition to a market economy substantially increased the amounts of private tutoring (supplied and demanded) in countries where it had not existed, including China, Vietnam, some African countries, and many Eastern European transition economies (Bray 1999a).

Second, tight linkages between education and work may result in intense competition for more education and thus private tutoring (Stevenson and Baker 1992). Private returns in the labor force are generally higher to higher education 
than to secondary education (Psacharopoulos and Patrinos 2004), and the gap appears to be widening in many developing and developed countries (Brunello, Comi, and Lucifora 2000; Bourguignon and Rogers forthcoming). These high returns can lead to intensely competitive behavior by students and their parents, including the use of private tutoring to increase chances of university admission. An extreme form of these linkages is "diploma disease" (Dore 1976), whereby firms and governments rely heavily on a university degree as an initial screening tool for employment, in the belief that the degree signals skills that contribute to productivity but are hard to measure directly. This phenomenon has arguably fueled the demand for private tutoring in a number of countries (see Rogers 1996 for a model of this effect based on the experiences of Japan and Korea).

Third, parents may resort to private tutoring to compensate for the poor quality of a deficient public education system (Kim and Lee 2004). Low pay levels and weak monitoring of teachers in the public system can also cause teachers to force tutoring on students (Buchmann 1999; Silova and Bray 2006a), as formalized in a theoretical model by Biswal (1999). ${ }^{6}$

Fourth, cultural values may explain why private tutoring is more prevalent in some countries. Such values may be particularly important in East Asia (Bray 1999a).

Little formal empirical research has been done to test these hypotheses. The only cross-country study that has looked at the macro (economywide) factors determining the use of private tutoring is Baker and others (2001). Using data on 41 countries participating in the Third TIMSS assessment, they find that higher public education expenditures (as a share of GNP) and gross enrollment rates predict lower use of private tutoring. A high-stakes testing system has no significant impact on private tutoring.

The first result suggests that private tutoring is more popular in countries with weak and deficient public education systems. The analysis does not control for per capita income levels, however. This omission may bias the results, because income levels are highly correlated with both public education expenditures and gross enrollment rates. ${ }^{7}$

\section{Impact of Private Tutoring on Student Learning}

Understanding the policy implications of the growth of the private tutoring industry requires understanding not only its determinants - who is investing in tutoring and why-but also the consequences for those being tutored. Does spending on private tutoring yield substantial returns for individual learners? For society as a whole?

In standard models the presumption is that private tutoring must yield substantial increases in learning, because most students consider tutoring an investment 
rather than consumption. If households consist of well-informed, sovereign consumers focused on learning - and ultimately on increased productivity in the workforce-one would expect significantly positive returns to individuals. But this is not the only possibility, for three reasons. First, consumers could be poorly informed about returns. Even econometricians find it challenging to tease out the returns to tutoring (as discussed below); it may be very hard for households to know for sure that their investment will pay off, particularly as any wage returns may be realized only after many years. Second, consumers may not be sovereign: parents who pay for tutoring may have objectives other than improving their children's learning and productivity, such as finding child care. Third, students may view tutoring as consumption rather than investment.

\section{Endogeneity: Unobserved Factors may Affect Both Investment in Private Tutoring and Student Performance}

Analyzing the evidence on learning gains attributable to tutoring is tricky because of the potential endogeneity of tutoring, which many studies have failed to address. For this reason this review of the literature focuses on the results from the handful of studies that have dealt with endogeneity.

A naive first approach to estimating the effects of private tutoring on performance would be to use micro-level data to estimate the following equation:

$$
A=\alpha+\beta T+\gamma \mathbf{X}+\epsilon
$$

where $A$ is a student's academic performance; $T$ is the student's attendance at or spending on private tutoring classes; $\mathbf{X}$ is a vector of other student, household, school, and community characteristics (for example, the student's age and gender, the household's socioeconomic status and place of residence, and school quality); $\epsilon$ is the error term; and $\alpha, \beta$, and $\gamma$ are the parameters to be estimated, with $\beta$ the estimated return to private tutoring.

This approach, at least as it is usually implemented, is likely to yield unreliable estimates of the coefficient on private tutoring, because students who receive private tutoring may differ in various unobserved but important dimensions from those who do not. One such dimension is the level of parental concern about their children's education. This variable is hard to measure and is therefore usually excluded from these analyses. Yet parents who place high value on their children's education may directly assist their children to succeed in school by helping them with their homework, for example, while also spending money on private tutoring.

Another example is a student's motivation for studies, which is also difficult to measure. Highly motivated students may be more willing to receive private tutoring than their less motivated peers, but they are likely also to outperform students who did not receive tutoring for reasons unrelated to tutoring. 
Private tutoring is thus endogenous, in that these unobserved factors affect both investment in private tutoring and the performance at school. If not properly controlled for in regression analysis, these unobserved characteristics will end up in the error term, rendering the estimation results inconsistent and unreliable. This selection bias is commonly addressed in other contexts in the education literature, such as estimating whether religious and other private schools yield better student outcomes than public schools do (see, for example, Bedi and Garg 2000 and Newhouse and Beegle 2006 for public-private comparisons in Indonesia).

Three econometric techniques have been used to deal with the endogeneity of private tutoring. The first - and perhaps cleanest-approach is to run experiments that randomly assign students into comparable treatment and control groups. With such a set-up, researchers can use a straight difference-in-difference comparison of the gains in education outcomes for the two groups to estimate the returns to private tutoring. ${ }^{8}$ Even with this arrangement, however, interpreting the results is challenging, because students cannot be assigned to purchase private tutoring. Such studies must provide free tutoring, which may differ from tutoring that is paid for. Providing tutoring free seems likely to reduce its effectiveness in promoting learning; if anything, this should bias downward the estimates of the returns to tutoring.

A second approach, implemented ex post using observational data, relies on quasi-experimental identification of the effects of tutoring by using a differencein-difference analysis as a program is rolled out across the country. Like the first approach, this approach has had to rely on tutoring provided by the program rather than purchased by households.

The third approach is to rely on instrumental variables that correlate with private tutoring attendance, expenditure, or both but that do not correlate with unobserved characteristics such as parental concern or student motivation. ${ }^{9}$ This approach has the advantage of measuring the effects of private tutoring sought as a result of household decisions rather than government programs. The disadvantage is that such estimates are likely to be more sensitive to econometric assumptions than are experimental and quasi-experimental estimates.

\section{Evidence on the Impact of Private Tutoring}

Research on the impact of private tutoring can be divided into studies that control for the endogeneity of private tutoring and those that do not (table 2). In addition to the standard type of tutoring paid for by the household, some studies include remedial education programs financed by sources other than households.

Studies that do not control for endogeneity yield mixed results on the impact of private tutoring on academic performance. They indicate that private tutoring has positive impacts in Japan (Stevenson and Baker 1992), Kenya (Buchmann 
Table 2. Effects of Private Tutoring in Selected Countries

\begin{tabular}{llll}
\hline Study & Country & Year & Level/grade/age
\end{tabular}

Main effect

Comment

Studies that control for endogeneity

Mischo and Haag Germany 1998-99 Grades 5-11

(2002)

Banerjee et al. India $\quad 2001-04 \quad$ Grades 3 and 4
(2007)

\section{Suryadarma \\ Indonesia 2002-03 Grade 4}

et al. (2006)

Lavy and

Schlosser (2005)
Israel
1999-2001 Underperforming high school students
Receiving private tutoring improved academic performance and motivational variables.

Remedial education program increased average test scores for all children in treated schools 0.28 standard deviation. Computer-assisted learning program increased math scores 0.47 standard deviations. One year after the program, initial gains were reduced to 0.1 standard deviation.

Private tutoring had no impact on mathematics or dictation scores.

Remedial education program increased the mean pass rate for the baccalaureate exam 3-4 percentage points for participating schools and 11-12 percentage points for participating students. Program expenditure per participant represented about 40 percent of the annual expenditure per high school student.
Study uses a form of matching in which students in tutoring identify a match in an attempt to account for unobserved differences between tutoring participants and nonparticipants.

Study uses randomized experiment method.

Variable indicating school clustering in terms of private tutoring is used as instrument for private tutoring. Study uses both difference-in-difference and instrumental variables methods. Instrumental variables for the proportion of students participating in the program include the interaction terms of school size, year dummy variable, and treatment status. 
Ono (2007) Japan $\quad 1995 \quad$ Male high school and

Briggs (2001)

United

$1990-92$

States

Jacob and Lefgren

(2004)

Dang $(2007 b)$

Vietnam

$1997-98$

Studies that do not control for endogeneity

Stevenson and Japan 1980-82

Baker (1992) university graduates

Years spent after high school graduation cramming in private tutoring centers (ronin) improved the quality of the university that students attend, thus raising earnings indirectly (through this improvement in college quality).

Commercial private tutoring courses increased SAT math scores 14-15 points, SAT verbal scores $6-8$ points, and ACT math and English scores 00.6 points; they decreased ACT reading scores $0.6-0.7$ points.

Summer remedial programs increased math and reading achievement by about 12 percent of average annual learning gains for third-graders and 6 percent for sixth-graders.

Private tutoring improved students academic performance.

\section{secondary schoo}

High school seniors
For students in the first year out of high school, practice exams increased probability of entering university 16 percent; correspondence courses increased probability 25 percent. For students in the second year out of high school, attending specia tutoring school increased probability
Study uses instrumental variables method but does not control for other household, school, or community characteristics (such as parental education or household income).

Study does not report variables used as instruments for private tutoring and does not control for school characteristics.

Study uses regression discontinuity method.

Study uses private tutoring fees charged by schools as instruments for students receiving private tutoring. 
Table 2. Continued

\begin{tabular}{|c|c|c|c|c|c|}
\hline Study & Country & Year & Level/grade/age & Main effect & Comment \\
\hline & & & & $\begin{array}{l}\text { of entering university } 80 \text { percent. } \\
\text { Having a private tutor significantly } \\
\text { reduced this probability, but this } \\
\text { result most likely reflects the remedial } \\
\text { character of this form of private } \\
\text { tutoring in Japan. }\end{array}$ & \\
\hline $\begin{array}{l}\text { Buchmann } \\
(2002)\end{array}$ & Kenya & 1995 & 13-18-year-olds & $\begin{array}{l}\text { Private tutoring reduced the chance of } \\
\text { repeating grades and increased } \\
\text { student academic performance. }\end{array}$ & $\begin{array}{l}\text { Study does not control for school } \\
\text { characteristics. }\end{array}$ \\
\hline $\begin{array}{l}\text { Lee and others } \\
\text { (2004) }\end{array}$ & $\begin{array}{l}\text { Republic } \\
\text { of Korea }\end{array}$ & $2000-01$ & Middle and high school & $\begin{array}{l}\text { Preclass tutoring (private tutoring that } \\
\text { teaches the school curriculum at least } \\
\text { one month ahead of schedule) had no } \\
\text { short- or long-term effects on student } \\
\text { academic performance. }\end{array}$ & $\begin{array}{l}\text { Study does not appear to account for } \\
\text { student motivation for receiving } \\
\text { private tutoring. }\end{array}$ \\
\hline $\begin{array}{l}\text { Cheo and Quah } \\
\text { (2005) }\end{array}$ & Singapore & Not reported & Grade 8 & $\begin{array}{l}\text { Time spent with private tutor had } \\
\text { negative impact on student academic } \\
\text { performance. }\end{array}$ & \\
\hline $\begin{array}{l}\text { Ha and Harpham } \\
(2005)\end{array}$ & Vietnam & 2002 & Eight-year-olds & $\begin{array}{l}\text { Private tutoring had no significant } \\
\text { effect on writing and multiplication } \\
\text { test scores but doubled reading scores. }\end{array}$ & $\begin{array}{l}\text { Study does not control for school } \\
\text { characteristics. }\end{array}$ \\
\hline
\end{tabular}


2002), and Vietnam (Ha and Harpham 2005) and negative impacts in Korea (Lee, Kim, and Yoon 2004) and Singapore (Cheo and Quah 2005). The results from these studies should be interpreted with caution, however, because of the endogeneity resulting from self-selection into tutoring (as some of the studies acknowledge). In addition, two of these studies do not control for school characteristics, which may further bias the estimation results.

Studies that control in some credible way for the endogeneity of private tutoring generally find that private tutoring boosts student academic performance. Tutoring is found to increase test scores in India (Banerjee and others 2007), mean pass rates on the baccalaureate exams in Israel (Lavy and Schlosser 2005), the quality of universities students attend in Japan (Ono 2007), Scholastic Aptitude Test (SAT) and ACT test scores (except for ACT reading scores) and academic performance in the United States (Briggs 2001; Jacob and Lefgren 2004), ${ }^{10}$ and student academic performance in Vietnam (Dang 2007b). The sole exception is in Indonesia (Suryadarma and others 2006), where tutoring was not associated with higher performance by fourth graders. ${ }^{11}$ No studies appear to have examined whether the estimated negative correlations between private tutoring and achievement in Korea and Singapore change when endogeneity is properly addressed.

The three studies on India, Israel, and Vietnam are examined in some detail because they include cost data, making it possible to consider both the impact of tutoring on academic performance and the cost-effectiveness of tutoring. Furthermore, these studies reflect the variation in the usage and financing of tutoring. They include both low-income (India and Vietnam) and high-income (Israel) countries; they include estimation of tutoring effects on students of all academic abilities (Vietnam) and on underperforming students (India and Israel); and they include tutoring that is financed by a nongovernmental organization (NGO; India), publicly financed (Israel), and financed by households (Vietnam).

NGO-financed Remedial Tutoring in India. Pratham, a large Indian NGO, financed the implementation of a two-year in-school randomized tutoring program that targets poor children in two large cities. This remedial education program targeted children in grades 3 or 4 who had not mastered basic skills. These students were taken out of their classrooms and given two hours of supplemental instruction each day by young women from the community.

Banerjee and others (2007) find that this tutoring program improved student test scores by large and statistically significant amounts. Children randomly assigned to the treatment group improved their test scores by 0.6 standard deviations in the second year; control group children remaining in the regular classroom did not benefit. Overall, the test scores of children in schools participating in the program rose 0.14 standard deviations in the first year and 0.28 standard 
deviations in the second year. These gains fell substantially one year after the program ended, however. More research is needed on the long-term impact of such programs.

Banerjee and others attribute the relative success of the program to regular teachers' lack of motivation to help lagging students and to the common background shared by the students and the tutors. They also show that this tutoring program is cost-effective. At about $\$ 10-\$ 15$ a month, the tutors' salary is equivalent to just $6-10$ percent of the salary of a starting teacher. They calculate that scaling up the tutoring program would be much more cost-effective than hiring new teachers, at least in terms of raising test scores. The program, which has already reached tens of thousand of children across India, is estimated to cost about $\$ 2.25$ per student a year.

A second program used computers, rather than human tutors, to deliver the tutorials. This program raised math scores by 0.36 standard deviations the first year and 0.54 standard deviations the second year. However, it is much more expensive than the first program, at $\$ 15.18$ per student a year.

Government-financed Remedial Tutoring in Israel. Israel has been operating a remedial education program for underperforming high-school students since 1999. By 2004 the program was reaching about a third of all high schools (Lavy and Schlosser 2005). The objective of the program is to increase the number of students who earn baccalaureate certificates by providing them with increased instructional time. In each school the program identifies up to five students in the 10th, 11th, and 12th grades judged most likely to fail the exams. The classroom teachers then provide these students with after-school tutoring in the subjects in which they are weak.

To examine the effects of the program, Lavy and Schlosser (2005) use a quasiexperimental difference-in-difference methodology (supplemented by instrumental variables as an alternative identification strategy). Their approach relies on the fact that the program was rolled out over time, allowing them to compare learning gains in schools that received it early on with those in schools that received it later.

Lavy and Schlosser find that the program had a positive impact on both the students and the participating schools. The program increased the probability of a tutored student earning a baccalaureate certificate by 12 percentage points, an average improvement of 22 percent over the base rate. The targeted schools saw an increase of about 3.3 percentage points in mean pass rates on the baccalaureate exams, equivalent to an improvement of 6 percent over the base rate. The program did not appear to affect nontutored students.

At $\$ 1,100$ per tutored student (about 40 percent of annual expenditure per high school student in Israel) the average cost of the program is very high. Nevertheless, Lavy and Schlosser estimate the program's internal rate of return at 
20 percent. Although this makes the remedial tutoring program less cost-effective than two other incentive-based programs in Israel examined by the authors, 20 percent is an impressive rate of return.

Household-financed Tutoring in Vietnam. Private tutoring is very popular in Vietnam, with about 34 percent of households with children in school purchasing private lessons. Ninety percent of these households allocate 1-5 percent of total household expenditure to private tutoring. Some 31 percent of primary students, 56 percent of lower-secondary students, and 77 percent of upper-secondary school students receive private tutoring (Dang 2007b).

Dang addresses the endogeneity of tutoring with an instrumental variables strategy that uses tutoring prices as the instrument. Using data from the Vietnam Living Standards Surveys for 1992-93 and 1997-98 he shows that private tutoring improves student academic performance. After controlling for other individual, household, school, and community characteristics he finds that raising annual spending on private tutoring from 0 to 20,000 dong (D) - about $\$ 1.50$ in 1998, equivalent to about 0.4 percent of mean consumption or 2 percent of spending on education by households with children in school-has strong positive effects on performance. For primary school students, tutoring reduces the probability of obtaining a "poor" academic ranking by about 1 percentage point, reduces the probability of average performance by 4 percentage points, and increases the probability of good or excellent performance by 5 percentage points. For the same increase in expenditure at the lower-secondary level it reduces the probability of poor performance by about 1 percentage points, reduces the probability of average performance by 7 percentage points, and increases the probability of good or excellent performance by 8 percentage points.

These estimates can be used to make a rough calculation of the cost-effectiveness of tutoring in promoting grade progression among lower-secondary school students. Students with "poor" academic rankings usually have to repeat grades in Vietnam. A year of lower-secondary schooling has a total cost (direct costs to households and the government plus assumed opportunity cost of forgone wages) of about D3 million a year. Everything else being equal, if the household's aim is for the child to complete a given level of education, a reduction of 1 percentage point in the probability of earning a "poor" academic ranking reduces the expected costs of grade repetition by about D30,000. Similar calculations for primary students also show that D20,000 worth of private tutoring reduces the expected costs of grade repetition by about D25,000. ${ }^{12}$ This means that the benefits from lower repetition rates alone exceed the costs of tutoring. The total benefits are likely to be much higher, because these calculations do not account for any economic benefits of better academic ranking categories or for avoided psychological costs associated with grade repetition. 


\section{Interpreting the Evidence}

Recent studies that have dealt with the endogeneity of tutoring and estimated cost-effectiveness find that private tutoring has strong positive returns. Some caution is needed in interpreting the evidence, however, for several reasons. First, this line of analysis is made difficult by the nature of private tutoring transactions: typically it is the household (rather than an NGO or government) that decides whether to purchase private tutoring. It is hard to imagine how that decision could be randomized across households in order to obtain clean measurement of the returns to privately purchased tutoring. At best a government could randomize access to potential tutors - by, for example, flooding certain randomly chosen communities with unemployed graduates - and then examine whether households chose to consume more tutoring and if so how it affected student performance.

Second, estimation results from these studies should be considered in context and neither generalized to all students nor narrowed to specific subgroups of tutored students. Most of the studies cited in table 2 estimate only the average return for all students enrolled in tutoring. This approach implicitly assumes that all students share the same returns to private tutoring, regardless of their innate ability or socioeconomic background (exceptions include the studies by Jacob and Lefgren 2004; Lavy and Schlosser 2005; and Banerjee and others 2007.) If this homogeneity assumption is violated, the estimated benefits of tutoring will not apply to subgroups and may be biased as well (see Heckman, Lochner, and Todd 2006 and Heckman, Urzua, and Vytlacil 2006 for discussions of the heterogeneity in returns to education in instrumental variables models). For example, while the studies for India (Banerjee and others 2007), Israel (Lavy and Schlosser 2005), and the United States (Jacob and Lefgren 2004) show that remedial private tutoring improves student performance, this result may hold only for the grades evaluated.

It is not easy to take account of this heterogeneity in returns to private tutoring. Doing so requires detailed data on the student variables that may affect returns, as well as more sophisticated estimation techniques. Crafting more detailed policies demands more in-depth analysis of specific groups in particular contexts.

Third, the evidence presented here on the returns to investment in private tutoring refers only to private returns. Little is known about the social returns to private tutoring. Even if tutoring is completely financed by households, any externalities of private tutoring would need to be estimated before social returns could be calculated (but see discussion below on the social costs of tutoring in a signaling equilibrium).

Subject to these caveats, it appears that tutoring has strong positive private returns as a supplement to formal public school education. The programs on 
which there is evidence may provide good starting points for policymakers seeking to design and implement supplementary education programs.

\section{What Stance Should Policymakers Take toward Tutoring? Efficiency and Equity Considerations}

How does private tutoring affect efficiency and equity? This section first analyzes this question while maintaining the assumptions that the market is perfect and the supply curve for public schooling perfectly inelastic after a certain point. It then examines how these conclusions change when these assumptions are relaxed.

\section{Efficiency Considerations in the Standard Case}

The micro evidence on private tutoring suggests that it generally improves student academic performance for the average tutored student. More limited evidence suggests that these improvements can be cost-effective. A question for policymakers is whether, from a broader social perspective, the availability of private tutoring increases overall welfare. Are the societal gains from private tutoring likely to exceed its costs?

No studies appear to have been conducted on the efficiency of private tutoring at the macro level. However, combining the micro evidence with the analytical framework set forth above can help answer this question.

The availability of private tutoring increases efficiency and welfare, under certain assumptions revisited below (figure 1). For a household whose demand for education is represented by demand curve $D_{2}$, the availability of private tutoring raises consumption of education to $Q_{2}^{*}$. This is more than the amount of public education $\left(Q_{2}\right)$ that the household consumes in the absence of private tutoring and more than the amount of private education $\left(Q_{0}\right)$ that the household can afford. (If the household's demand for education is on the low-demand curve, $D_{1}$, the household would consume no private tutoring given this supply curve.) Household consumer surplus increases by the amount represented by the triangle $\mathrm{BCE}$. Tutors gain the producer surplus represented by the triangle ABE.

One other effect is not shown directly in figure 1. High-demand households that in the absence of private tutoring would have chosen private schools may now enroll their children in public school. As demand for public schools increases, the costs to the government might be expected to rise and the producer surplus to private schools to fall. But because public schools are assumed to be on the vertical portion of their supply curve - that is, they have reached their capacity - the 
quantity of education provided by the government (and therefore government outlays) does not actually increase. Standard micro analysis makes it clear that the total gains to households and tutors should exceed the losses in the private school sector. Thus offering the opportunity to supplement public education with private tutoring increases welfare for households and society as a whole-at least in the standard model.

\section{Equity Considerations in the Standard Case}

Suppose policymakers are convinced that a robust private tutoring sector improves welfare but worry that it may increase inequality. There is indeed reason for concern. More privileged households - those with higher income and more education who live in urban areas-invest more in tutoring than other households do, and private tutoring appears to increase learning achievements for these children, at least on average. If learning achievement translates into higher lifetime earnings, one would expect the availability of household-financed tutoring to increase social inequalities.

One should not be too quick to equate tutoring with increasing inequality, however, or to assume that an equity-focused government should try to limit tutoring, for several reasons. First, when the appropriate counterfactual-what would happen in the absence of a private tutoring sector-is specified, tutoring may not increase educational inequality by as much as suggested above. Even productive tutoring may confer only a minor advantage on children from wealthier and more-educated households, because these households already give their children educational advantages in many other ways-by providing them with more books, more learning equipment, and even full-time private schooling, for example, or by teaching their children themselves. Even if it were enforceable, a ban on private tutoring would likely simply redirect the education expenditures of better-off households into these other investments. Furthermore, access to supplementary private tutoring may benefit poorer households if it helps their children compete with wealthier children enrolled in private schools.

Second, tutoring may emerge as an unintended result of other government education policies, including some policies aimed at promoting equity. Imagine, for example, that the government substantially increases its per student financing for public education in poor (low-demand) neighborhoods. This would shift the supply curve $\left(S_{2}\right.$ in figure 1$)$ downward. If the shift is substantial enough, it will induce low-demand households to consume more education, including more private tutoring.

To control educational inequality, governments may find it more effective to attack its roots than to discourage tutoring, which is in part a symptom of inequality. Korea took this tack in 1974, when it sought to control the growth of 
private tutoring by adopting a secondary school equalization program (Kim 2005). That program switched to allocating secondary school entrance by lottery rather than examination, reducing the quality advantages of higher-ranking schools and the incentive for exam-preparation tutoring. While demand for tutoring has remained high, Korea is not generally believed to have severe intergenerational transmission of inequality through education.

Third, governments can use tutoring to improve equity. The householdfinanced tutoring in the market equilibrium in figure 1 benefits children from high-demand households, which tend to be wealthier, but governments and others can target special tutoring programs at underperforming students, as Israel (Lavy and Schlosser 2005) and the United States (Jacob and Lefgren 2004) have done. In effect, the government would be segmenting the market depicted in figure 1 by driving the supply curve downward for low-demand households only. In this case the equity implications are clearly positive, as long as the subsidy is financed progressively.

\section{What if the Availability of Tutoring Impedes Public School Improvements?}

The first assumption that needs to be relaxed is that public education is capacityconstrained - meaning that at the upper end of its range the supply of education is perfectly inelastic. This assumption is likely to hold only in the short term. Over the longer run, governments can and do take steps to increase the quantity of effective education, for example by expanding school capacity to allow longer schooling hours, improving teacher attendance and time on task, and ultimately hiring more teachers and building more schools. Such improvements extend the upward-sloping portion of the public supply curve in figure 1 and shift the vertical section outward.

Distinguishing between the short and long runs therefore matters. Under the earlier assumptions of the short-run standardized framework model depicted in figure 1, private tutoring occupied a neutral territory unaffected by the debate that pits public schools against private ones. Public and private schools are typically depicted as substitutes, which they generally are, at least at the level of the individual student (from the perspective of the school system as a whole, private schools may be viewed as a useful complement to government schools). But in the situation depicted in figure 1, tutoring is a complement to public schooling. It enables parents to invest in an optimal amount of education for their children, increasing both consumer and producer surplus.

Thus private tutoring and public education appear to be complements in the short run. In the long run-defined here as the time it takes to make substantial improvements in the quality and quantity of public schooling - private tutoring may substitute for public education. The availability of tutoring could diminish 
parents' interest in lobbying for long-term improvements in public education. If urban elites find that tutoring gives their children an advantage in competitive examinations or the labor market and they fear that any future public school improvements would go primarily to schools serving disadvantaged areas, they may prefer the status quo. In Japan it has been argued that education reforms to expand public school activities have been blocked by the dependence on private tutoring to perform these tasks (LeTendre 1994). The tutoring market may serve as an outlet releasing political pressure for reform and quality improvement.

In the long run, private tutoring may provide less of a spur to public quality than competition from private schools does. Some scholars (Hoxby 1994; Rouse 1998; Bishop and Wossman 2004) argue that the loss (or potential loss) of students to private schools puts pressure on public schools to improve quality. Private tutoring would likely have no such effect, because it does not cause students to abandon public schools.

The question is not whether private tutoring enables or undermines the public sector's role as a provider of education. Public schooling will continue to be a part of virtually every national primary and secondary school system. The point is simply that where tutoring is widespread, it will likely have important effects on the quality and efficiency of public schools. Policy will need to take account of these effects over both the short and long terms.

\section{What if Teacher Corruption makes the Tutoring Market Uncompetitive?}

A second assumption underlying the standardized model is that the market for tutoring is competitive. This may not be the case. Public school teachers may have substantial market power as suppliers of private tutoring, especially in remote rural areas, where they may be the only potential suppliers of private tutoring.

More worrisome is the fact that teachers who are corrupt and poorly monitored sometimes force their public school students to take private tutoring lessons from them or omit part of the curriculum during regular classroom hours and save it for their tutoring lessons (Buchmann 1999; Foondun 2002; Glewwe and Jayachandran 2006; Silova and Bray 2006a). Others give preferential treatment to particular children in return for a fee. This practice may reduce teacher time and energy in mainstream classes, or it may encourage teachers to work additional hours.

Teachers' monopoly power reduces the consumer surplus of high-demand consumers. The dysfunctional monitoring system coupled with teacher corruption blurs the line between public education and private tutoring. Graphically, this would increase the slope of the (now ostensibly public) supply curve $S_{2}$ and shift it to the left in figure 1, forcing households to pay a higher price for the same amount of education. The more market power teachers have, the farther leftward 
they may try to shift the supply curve. As one would expect, given teachers' monopoly power, consumer surplus falls by more than the gain in producer surplus to the teacher. In such cases, private tutoring is not likely to yield the substantial returns to tutoring documented in the empirical studies cited above.

This outcome is worse than the no-corruption competitive private tutoring equilibrium; for households it may also be worse than having no tutoring at all. In the worst case, tutoring fees are simply a net transfer from households to teachers: the amount of education provided remains the same, but the teacher delivers part of it for a fee outside of school hours. In rural areas, where teacher governance is poor and this type of corruption is most likely to flourish, the transfer will usually be regressive, because teachers tend to have considerably higher incomes than the average rural resident. Moreover, evidence on service delivery suggests that it is the poorest households that suffer most from failures in service delivery (World Bank 2003) and pay the largest bribes relative to their consumption level (Hunt and Laszlo 2005). As a result, the transfer will likely reduce equity and overall welfare.

This analysis of potential teacher corruption suggests that in the absence of mechanisms to control teacher corruption, allowing private tutoring may be counterproductive in some cases. Given the difficulties and undesirability of banning tutoring outright, it provides a rationale for measures to prevent public school teachers from tutoring their own students privately. Ukraine's education ministry imposed such a ban in 2004 in response to complaints from parents that teachers were providing "compulsory private tutoring" (Hrynevych and others 2006).

\section{What if the Purpose of Tutoring is not only to Increase Human Capital?}

How does the diagnosis change if tutoring is not necessarily productive from a societal perspective? The analysis assumed that an increase in education units consumed not only increases a student's future productivity (and hence wages) but also increases societal productivity by an equivalent amount. In theory this need not be the case. If tests measure student characteristics that have signaling value but no productive value, tutoring may not increase the productivity of tutored students, even though it increases their wages. This would be the extreme version of the signaling model introduced by Spence (1973). In such a signaling equilibrium policymakers would be right to worry about the social costs of the tutoring industry, which would in essence be an arms merchant in a negativesum education arms race.

While this extreme theoretical case certainly does not apply anywhere, criticism of some aspects of otherwise high-performing education systems in Korea and Japan-both of which have very large private tutoring sectors-has cited the 
perceived uselessness of some of the material tutoring students master in preparation for university entrance examinations. Concerns about the heavy financial burden of tutoring on parents have led to reform in Korea (Kim 2001).

These concerns are consistent with the argument that the long-term financial returns do not justify the costs of private tutoring. Empirical evidence suggests a bunching of private tutoring investment immediately before school-leaving or university entrance exams, which is consistent with a signaling story. Standardized tests for admission to law school in the United States, which have given rise to a large test-preparation industry, have been criticized for being widely used despite their inability to predict applicants' performance as lawyers (Haddon and Post 2006). The fact that students in the United States prepare for the Law School Admission Test (LSAT) — supposedly an aptitude test-by acquiring test-taking skills taught in tutoring courses suggests that the test results contain an element of signaling. If tutoring were contributing only to productive human capital, it would not likely raise scores on an aptitude test, at least not as a result of the short courses offered by tutoring companies.

Although it is analytically difficult to distinguish between the signaling and productive human capital stories, signaling incentives are likely to explain some tutoring in societies that make heavy use of tutoring (Rogers 1996; Chae, Hong, and Lee 2004; Lee 2007). But three points should be kept in mind. First, although a (partial) signaling story changes the situation depicted in figure 1 to a degree, it does not qualitatively change the conclusions. A signaling equilibrium makes the slope of the private tutoring supply curve steeper, by reducing the effective units of education (human capital) received, but the outcome does not change fundamentally.

Second, countries such as Korea that apparently make greater use of signaling are among the highest performers on well-designed, internationally normed student assessments such as the Programme for International Student Assessment (PISA) and the TIMSS. These high scores suggest that students are acquiring a large amount of real human capital even if they are also investing in signaling value.

Third, the appropriate response in the signaling case is probably not to discourage tutoring — as Korea did in 1980 by banning it—but to address the problem at its source. The government could, for example, revise university admissions policies so that they place less reliance on a single examination, which makes for a tempting signal of a student's ability.

\section{Policy Implications}

The evidence suggests that tutoring can raise educational outcomes as a complement to formal school systems. In the absence of corruption, and given the 
assumptions discussed above, private tutoring increases the welfare of households and society as a whole. Private tutoring may place poorer households at some disadvantage relative to richer households, however, particularly when corruption distorts the tutoring market. Corruption also reduces the efficiency of the tutoring equilibrium. This section explores what these drawbacks imply for education policy in developing countries.

\section{Government Policy and the Control of Corruption}

Before turning to policy recommendations, it is useful to consider the policies governments have implemented. Bray (2003) divides governments into four types: those that ban private tutoring (type I), those that ignore it (type II), those that recognize and regulate it (type III), and those that actively encourage it (type IV; table 3).

Bray and Silova (Bray 2003, 2006; Silova and Bray 2006b) offer helpful detail on the different types of governments. They note that type I governments all failed in their attempts to ban private tutoring. Bans in Cambodia and Myanmar failed because those countries' institutions were too weak to implement the policy. In Korea and Mauritius the bans faced too much opposition from vested interests, forcing the governments to lift the bans and regulate private tutoring.

Type II governments ignore private tutoring. These governments can be divided into two groups based on their reasons for ignoring private tutoring. Countries in the first group (including Nigeria and Sri Lanka) have weak institutions and little capacity to monitor private tutoring. Countries in the second group (including Canada and the United Kingdom) have stronger institutions and adequate capacity to monitor private tutoring. They choose not to regulate the sector, either because they consider it to have small and insignificant effects or because they prefer to let market forces govern the sector.

Type III governments (such as Hong Kong, China; Mauritius; and Vietnam) take a more active role in controlling private tutoring. These governments recognize the importance of private tutoring and attempt to control it both directly and indirectly. They may prohibit private tutoring in early grades; forbid teachers from tutoring their own students; stipulate fees, class sizes, or syllabi for private tutoring classes; and reduce disparities across schools.

Type IV governments (including Singapore, South Africa, Tanzania) actively encourage private tutoring. These governments believe that private tutoring contributes to human capital development and that private tutoring is an effective means of tailoring education to the needs of students. Policies in type IV countries range from offering general encouragement to providing subsidies for private tutoring, training courses for tutors, and tax incentives.

It may be useful to add another dimension to this framework: control of corruption (see table 3). By this measure (taken from Kaufmann, Kray and Mastruzzi 
Table 3. Government Policies toward Private Tutoring in Selected Economies

\begin{tabular}{|c|c|c|c|c|}
\hline Type & Policy & Measure & Country & Comment \\
\hline I & $\begin{array}{l}\text { Prohibit private } \\
\text { tutoring }\end{array}$ & Total ban on private tutoring. & $\begin{array}{l}\text { Cambodia (7), Republic of Korea (65), } \\
\text { Myanmar (1), Mauritius (67) }\end{array}$ & $\begin{array}{l}\text { Tutoring was banned, but the bans were } \\
\text { ineffective because of government's } \\
\text { inability to enforce them. }\end{array}$ \\
\hline \multirow[t]{2}{*}{ II } & $\begin{array}{l}\text { Ignore private } \\
\text { tutoring }\end{array}$ & & $\begin{array}{l}\text { Croatia (58), Georgia (45), Nigeria (6), } \\
\text { Mongolia (37), Sri Lanka (49) }\end{array}$ & $\begin{array}{l}\text { Most of these countries have weak } \\
\text { institutions and do not have the } \\
\text { capacity to regulate private tutoring. }\end{array}$ \\
\hline & & & Canada (94), United Kingdom (94) & $\begin{array}{l}\text { These countries have strong institutions } \\
\text { and the capacity to regulate private } \\
\text { tutoring, but they consider the private } \\
\text { tutoring market outside of their sphere } \\
\text { of responsibility. }\end{array}$ \\
\hline
\end{tabular}
III Recognize and regulate private tutoring

Generally prohibit private tutoring in early grades and prohibit teachers from tutoring their own students. Regulations are accompanied by inspections and sanctions on private tutoring fees, class sizes, and syllabi. Regulations are placed on infrastructure of private tutoring centers. Policies seek to reduce stratification in the education system, reduce disparities in schools, and raise public awareness about negative effects of private tutoring.
Hong Kong (China) (93), Lithuania (60), Republic of Korea (65), Mauritius (67), Ukraine (28), Vietnam (29) 
IV Actively encourage Provide subsidies for private tutoring, private tutoring disseminate information to link potentia

tutors and clients, offer training courses for tutors, and provide tax incentives for
Singapore (98), South Africa (71),

Tanzania (43)
These countries believe that private tutoring contributes to human capital development and caters to the needs of students.

\section{tutoring.}

Note: Measures shown are for illustration purposes only; countries in each category may not implement all measures. The numbers in parentheses indicate percentile ranking in control of corruption (higher rankings represent greater control). The timing of the corruption measure does not always coincide with the timing of government actions. However, in all countries except Tanzania there has been little change in this index over time.

Source: Bray (2003, 2006); Silova and Bray (2006b); for Croatia, Dedic and others (2006); for Mongolia, Matiashvili and Kutateladze (2006); for Georgia, Dong and others (2006); for Lithuania, Budiene and Zabulionis (2006); for Ukraine, Hrynevych and others (2006); and for Vietnam, Dang (2007a). Corruption rankings are from Kaufmann, Kray, and Mastruzzi (2007). 
2007), the first group in type I governments appears to have weak control of corruption, while the second group has sound control of corruption. (It should be remembered that neither group was successful in banning private tutoring.) Among type II governments, the first group has only weak to moderate control over corruption, while the second group has strong control. Control in Type III governments ranges from weak to strong; control in type IV governments ranges from moderate to strong. These associations between type and governance quality should be useful in gauging the feasibility of different policies.

\section{A (tentative) Agenda for Policy Toward Private Tutoring}

Some tentative policy recommendations can be proposed based on these results and the casual (but intuitive) observations about the association between corruption and government policies. First, since private tutoring is widespread and growing, it is time for governments to devote more attention to it. The benign neglect policy of type II governments runs the risk of letting tutoring-related corruption go unchecked in countries with weak control over corruption. Even countries in this group with stronger control over corruption may be missing opportunities to use tutoring to address imbalances between education supply and demand. Possible government actions range from monitoring (for example, collecting data on private tutoring attendance and private tutoring businesses) to trying to ensure that private tutoring can operate free of corruption and unnecessary barriers to competition.

There is still too little empirical evidence on the macro-level determinants of private tutoring. In particular, more cross-country data need to be collected to allow researchers to tease out the impacts of government policies and interventions (including, for example, education subsidies, public expenditure on education, high-stakes testing systems) on creating demand for private tutoring.

At the micro level, more research should be conducted on the household decision to send children to school (for example, the choice of private education over public education, with or without private tutoring; the choice between investing in the quantity and the "quality" of children), as well as the short- and long-term effects of private tutoring on student well-being (for example, student satisfaction levels, health status, labor-market outcomes, and so forth). Research should also investigate whether social returns to private tutoring differ from private returns.

Second, while it may be welfare enhancing to ban private tutoring when all tutoring is provided by corrupt teachers, a total ban is difficult to implement and is likely to have the unintended effect of preventing more beneficial tutoring by tutors who are not corrupt. Resources would be better allocated to monitoring and regulating - rather than trying to eradicate-private tutoring. Regulatory 
approaches can focus on reducing opportunities for corruption by prohibiting public school teachers from tutoring their own students.

Third, private tutoring markets in economies with low levels of corruption are likely to be more competitive than those in economies in which corruption is more entrenched. If this is the case, private tutoring is likely to be welfare enhancing. Governments may even want to encourage the private tutoring industry, as Singapore, South Africa, and Tanzania have done. Policymakers should monitor the development of the industry and address concerns. This may require going to the root of the education quality problem rather than holding the private tutoring sector responsible. Where tutoring appears to exacerbate social and geographical inequalities, government action will be most effective if it targets the source of the underlying inequalities, possibly by equalizing public school finance across rich and poor districts.

Finally, governments may want to explore financing tutoring programs as a flexible means of educating disadvantaged children. While more evidence is needed, the findings on targeted government- and NGO-financed tutoring programs suggest that this can be an effective means of improving education outcomes for disadvantaged children. Such programs have the added benefit of avoiding any equity-efficiency tradeoffs: by increasing the productivity of disadvantaged children, they promote equity goals as well.

\section{Appendix A}

Table A.1. Incidence of Private Tutoring in Selected Countries

\begin{tabular}{|c|c|c|c|c|c|}
\hline Source & Country & Year & $\begin{array}{c}\text { Level, grade, or } \\
\text { age }\end{array}$ & $\begin{array}{c}\text { Percentage of } \\
\text { students tutored }\end{array}$ & Comment \\
\hline \multirow[t]{2}{*}{$\begin{array}{l}\text { Silova and } \\
\text { Kazimzade (2006) }\end{array}$} & Azerbaijan & 2004 & $\begin{array}{l}\text { Secondary } \\
\text { school }\end{array}$ & 57 & \\
\hline & & & University & 92 & $\begin{array}{l}\text { First-year university } \\
\text { students received } \\
\text { private tutoring in } \\
\text { their last year of } \\
\text { secondary school. }\end{array}$ \\
\hline Ahmed et al. (2005) & Bangladesh & 2004 & $\begin{array}{c}\text { Primary } \\
\text { school }\end{array}$ & 43 & $\begin{array}{l}\text { More boys received } \\
\text { tutoring than girls. }\end{array}$ \\
\hline Bray (1999b) & Cambodia & $1997-98$ & $\begin{array}{l}\text { Primary } \\
\text { school }\end{array}$ & 31 & $\begin{array}{l}\text { Some } 90 \text { percent of } \\
\text { students in urban } \\
\text { schools and } 9 \\
\text { percent in rural }\end{array}$ \\
\hline
\end{tabular}


Table A.1. Continued

\begin{tabular}{|c|c|c|c|c|c|}
\hline Source & Country & Year & $\begin{array}{l}\text { Level, grade, or } \\
\text { age }\end{array}$ & $\begin{array}{c}\text { Percentage of } \\
\text { students tutored }\end{array}$ & Comment \\
\hline & & & & & $\begin{array}{l}\text { schools received } \\
\text { private tutoring. }\end{array}$ \\
\hline CME (2000) & Canada & 1999 & $\begin{array}{l}\text { 13- and 16- } \\
\text { year-olds }\end{array}$ & $\begin{array}{l}\text { 5-17 for 13-year- } \\
\text { olds, } 8-20 \text { for } \\
\text { 16-year-olds }\end{array}$ & \\
\hline $\begin{array}{l}\text { Aurini and Davies } \\
(2004)\end{array}$ & Canada & 1997 & $\begin{array}{l}\text { School-age } \\
\text { children }\end{array}$ & n.a. & $\begin{array}{l}\text { Between } 1974 \text { and } \\
2004 \text {, the number } \\
\text { of formal tutoring } \\
\text { businesses in major } \\
\text { Canadian cities } \\
\text { grew } 200-500 \\
\text { percent. }\end{array}$ \\
\hline $\begin{array}{l}\text { Stylianou et al. } \\
\text { (2003) }\end{array}$ & Cyprus & 2003 & University & 86 & $\begin{array}{l}\text { The surveyed } \\
\text { university students } \\
\text { reported that they } \\
\text { received private } \\
\text { tutoring in upper } \\
\text { secondary school. }\end{array}$ \\
\hline $\begin{array}{l}\text { Suliman and El- } \\
\text { Kogali (2002) }\end{array}$ & $\begin{array}{l}\text { Egypt, Arab } \\
\text { Rep. of }\end{array}$ & 2000 & $\begin{array}{l}\text { Children 6- } \\
15\end{array}$ & 71 & $\begin{array}{l}\text { Data are from Egypt } \\
\text { Demographic and } \\
\text { Health Survey. }\end{array}$ \\
\hline $\begin{array}{l}\text { Psacharopoulous } \\
\text { and } \\
\text { Papakonstantinou } \\
(2005)\end{array}$ & Greece & 2000 & University & $\begin{array}{l}80 \text { percent } \\
\text { attended group } \\
\text { (cram) } \\
\text { preparatory } \\
\text { schools, } 50 \\
\text { percent received } \\
\text { individual private } \\
\text { tutoring, } 33 \\
\text { percent received } \\
\text { both group and } \\
\text { individual } \\
\text { tutoring }\end{array}$ & \\
\hline $\begin{array}{l}\text { Bray and Kwok } \\
(2003)\end{array}$ & $\begin{array}{l}\text { Hong Kong, } \\
\text { China }\end{array}$ & $1996-98$ & $\begin{array}{l}\text { Secondary } \\
\text { school }\end{array}$ & $\begin{array}{l}35 \text { percent in } \\
\text { grades } 1-3 ; 47 \\
\text { percent in grades } \\
4-5 ; \text { and } 70 \\
\text { percent in grades } \\
6-7\end{array}$ & \\
\hline NCES (1996) & Japan & 1995 & Grade 8 & $\begin{array}{l}64 \text { percent of } \\
\text { eighth graders } \\
\text { received weekly }\end{array}$ & $\begin{array}{l}\text { Data are from } 1995 \\
\text { Trends in } \\
\text { International }\end{array}$ \\
\hline
\end{tabular}


Table A.1. Continued

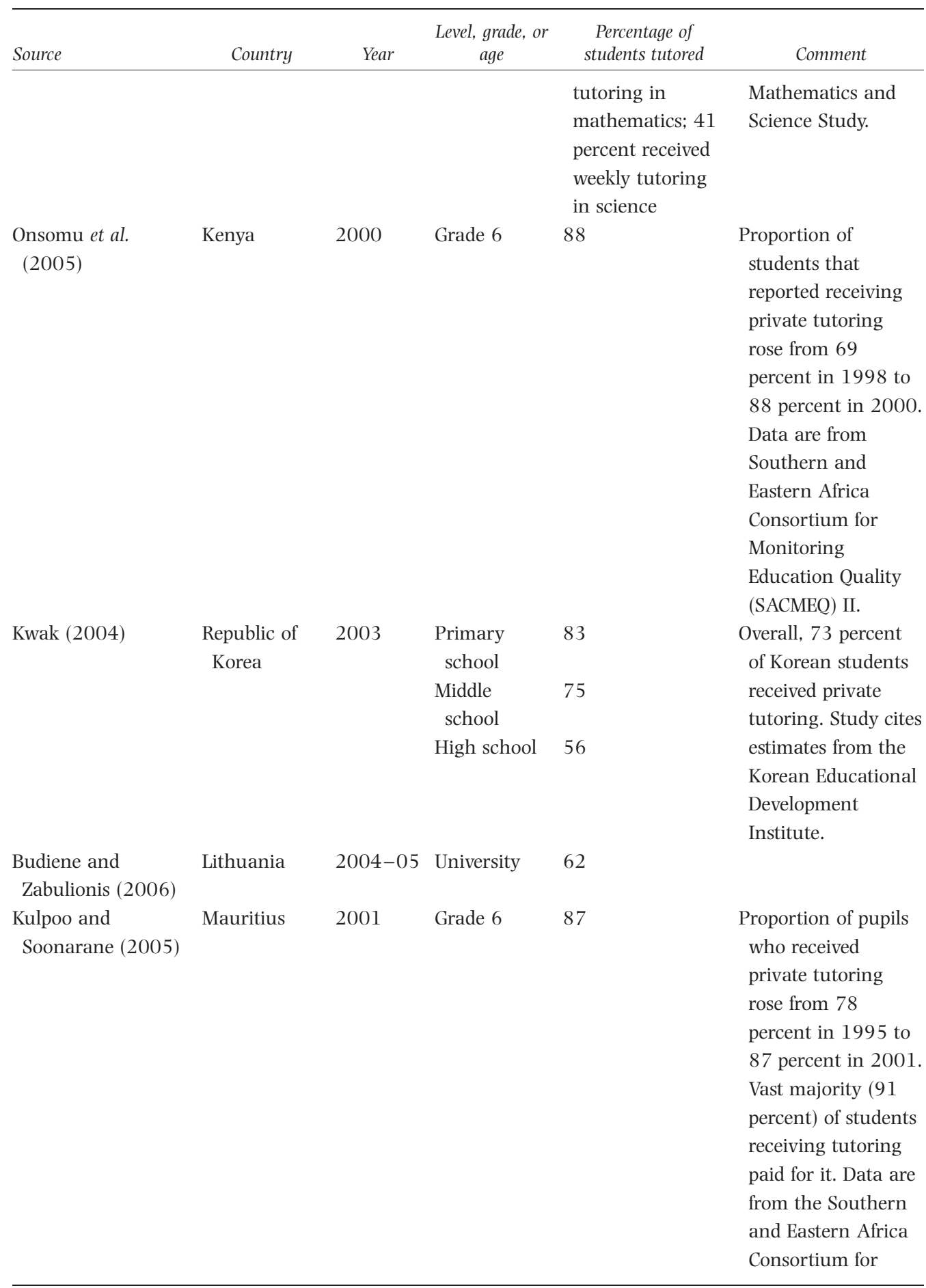


Table A.1. Continued

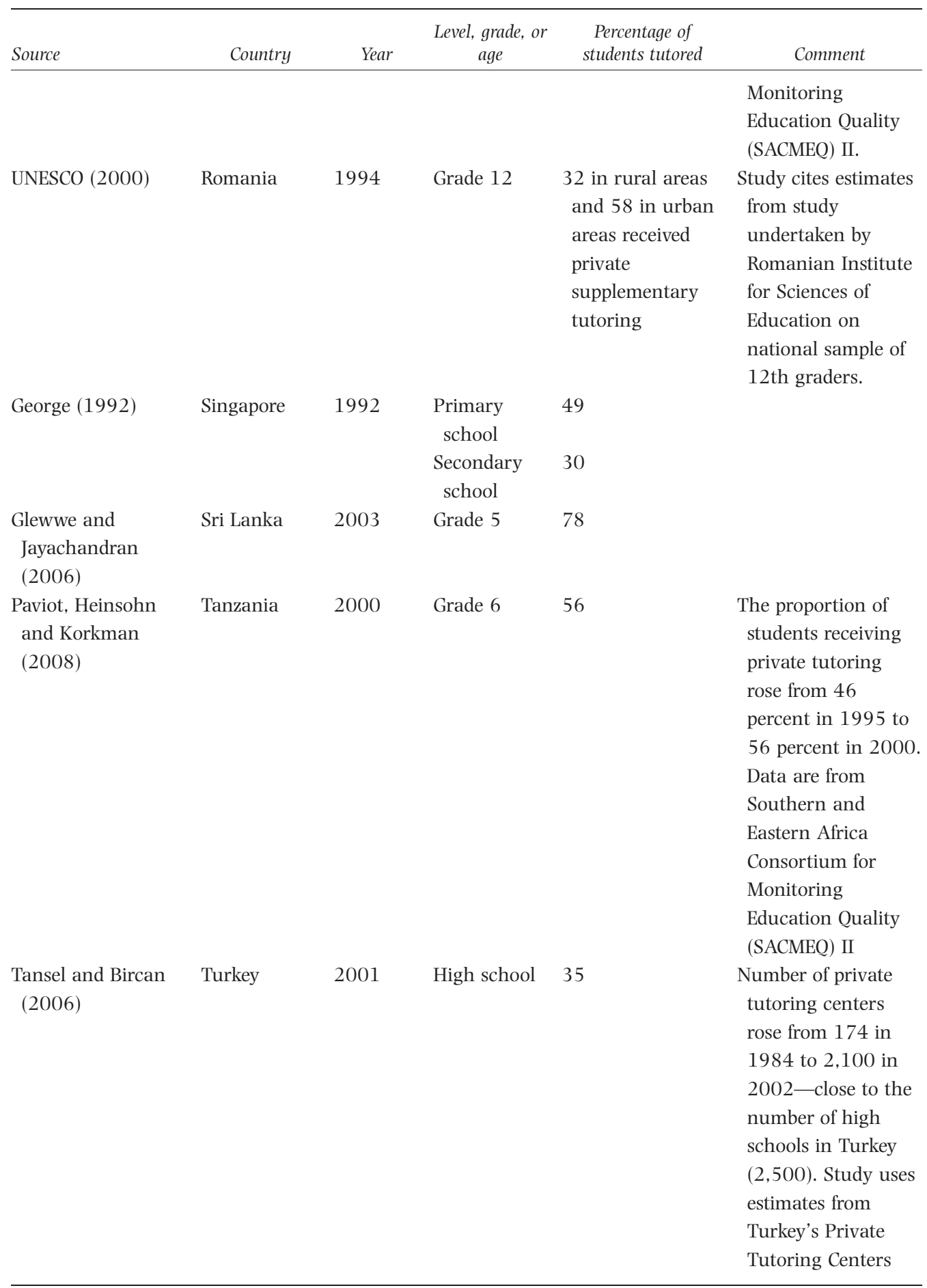


Table A.1. Continued

\begin{tabular}{|c|c|c|c|c|c|}
\hline Source & Country & Year & $\begin{array}{l}\text { Level, grade, or } \\
\text { age }\end{array}$ & $\begin{array}{c}\text { Percentage of } \\
\text { students tutored }\end{array}$ & Comment \\
\hline $\begin{array}{l}\text { Hrynevych et al. } \\
(2006)\end{array}$ & Ukraine & 2004 & University & 68 & $\begin{array}{l}\text { Association in } \\
2003 . \\
\text { Students received } \\
\text { private tutoring } \\
\text { during last year of } \\
\text { secondary school. }\end{array}$ \\
\hline $\begin{array}{l}\text { Ireson and } \\
\text { Rushforth (2005) }\end{array}$ & $\begin{array}{l}\text { United } \\
\text { Kingdom }\end{array}$ & 2003 & $\begin{array}{c}\text { Grades } 6 \\
\text { and } 11 \\
\text { Grade } 13\end{array}$ & $\begin{array}{l}26 \\
30\end{array}$ & \\
\hline $\begin{array}{l}\text { Gordon and Gordon } \\
\text { (2003) }\end{array}$ & United States & 2000 & $\begin{array}{l}\text { Elementary } \\
\text { school }\end{array}$ & n.a. & $\begin{array}{l}\text { Almost } 7 \text { million } \\
\text { elementary school } \\
\text { students are } \\
\text { believed to have } \\
\text { received tutoring; } \\
\text { tutoring industry } \\
\text { earned } \$ 5-8 \\
\text { billion. }\end{array}$ \\
\hline Briggs (2001) & United States & $1990-92$ & High school & $\begin{array}{l}\text { 14-21 percent } \\
\text { took special } \\
\text { courses to } \\
\text { prepare for SAT/ } \\
\text { ACT; } 8-14 \\
\text { percent received } \\
\text { private group } \\
\text { tutoring } \\
\text { (commercial } \\
\text { coaching } \\
\text { classes); } 6-8 \\
\text { percent received } \\
\text { one-to-one } \\
\text { private tutoring }\end{array}$ & \\
\hline Dang (2007b) & Vietnam & $1997-98$ & $\begin{array}{l}\text { Primary } \\
\text { school } \\
\text { Lower- } \\
\text { secondary } \\
\text { school } \\
\text { Upper- } \\
\text { secondary } \\
\text { school }\end{array}$ & $\begin{array}{l}31 \\
56\end{array}$ & $\begin{array}{l}\text { About } 34 \text { percent of } \\
\text { households with } \\
\text { children in school } \\
\text { sent their children } \\
\text { to private tutors, } \\
\text { with } 90 \text { percent of } \\
\text { them allocating } \\
\text { 1-5 percent of } \\
\text { household } \\
\text { expenditure to } \\
\text { private tutoring. }\end{array}$ \\
\hline
\end{tabular}


Table A.1. Continued

\begin{tabular}{|c|c|c|c|c|c|}
\hline Source & Country & Year & $\begin{array}{l}\text { Level, grade, or } \\
\text { age }\end{array}$ & $\begin{array}{c}\text { Percentage of } \\
\text { students tutored }\end{array}$ & Comment \\
\hline $\begin{array}{l}\text { Machingaidze et al. } \\
\text { (1998) }\end{array}$ & Zimbabwe & 1995 & Grade 6 & 61 & $\begin{array}{l}\text { Prevalence of } \\
\text { tutoring ranged } \\
\text { from } 36 \text { to } 74 \\
\text { percent across } \\
\text { regions. }\end{array}$ \\
\hline
\end{tabular}

n.a., not available.

Source: Based largely on Table II.1 in Dang (2007a).

\section{Notes}

Hai-Anh Dang is a consultant in the Development Research Group at the World Bank; his email address is hdang@worldbank.org. F. Halsey Rogers is a senior economist in the Development Research Group at the World Bank; his email address is hrogers@worldbank.org. The authors are grateful to Emmanuel Jimenez, Mark Bray, Henry Levin, and three anonymous referees for constructive comments. The authors would like to thank the Hewlett Foundation for its support (grant number 2005-6791). An earlier version of this paper was published as World Bank Policy Research Working Paper 4530 under the title "How to Interpret the Growing Phenomenon of Private Tutoring: Human Capital Deepening, Inequality Increasing, or Waste of Resources?"

1. The focus in this article is on private tutoring for academic subjects. Lipscomb (2007) and Barron, Ewing, and Waddell (2000) among others examine how nonacademic extracurricular involvement affects academic achievement.

2. The number of private tutoring colleges listed in the Yellow Pages in Sydney - the largest city in Australia-increased from 60 in 1989 to 222 in 2002 (Kenny and Faunce 2004). More evidence on the growth of private tutoring for several countries in Southern and Eastern Africa can be found in Paviot, Heinsohn, and Korkman (2008).

3. The public education system is known for its rigidity, lack of teacher incentives and accountability, and inadequate infrastructure, particularly in developing countries (Glewwe and Kremer 2006). Teacher absenteeism is also common in many countries (Chaudhury and others 2006). The supply curve need not become completely inelastic at the upper end (it is shown as such here only for ease of exposition); all that is necessary is that at the margin the public system be less able or willing to provide additional lessons than the private tutoring sector is.

4. Note that this is the (subsidized) public education supply curve- that is, the supply curve as viewed by households - not the underlying marginal cost of supplying public education. The cost of public schooling to households is assumed to be less than the cost of private schools, even though the underlying cost for private schools to produce education may be lower. No assumptions are made about the unit cost of private tutoring relative to the unit cost of private schools; the advantage of private tutors is their flexibility and ability to supplement the public system by providing as many additional hours (lessons) as households demand.

5. The dependent variables and other control variables differ across the models used in the studies for each country. The study of Japan, for example, looks at the probability that students participate in after-school private tutoring classes. The other studies assess the determinants of expenditure on private tutoring at the household or child level. Only the study of Egypt controls for parental presence in the household, and only the study of Turkey controls for whether the mother is single. 
6. One rebel group in the northeastern state of Manipur in India has reportedly forbidden teachers and professors to provide private tutoring classes, in an attempt to stop the widespread situation in which they do not come to class because they are too busy supplementing their low salaries by tutoring. Not surprisingly, even the government-appointed official in charge of higher education in Manipur sympathizes with the rebels' efforts (Chronicle of Higher Education 2003).

7. The direction of bias depends on the correlation between income levels and the private tutoring variables. If this correlation is positive, the coefficients on the share of public expenditure in GNP and gross enrollment rates would be biased upward; if they are negative, the coefficients would be biased downward.

8. Difference-in-difference comparisons of randomized control trials treat the before-to-after changes in the control group as a baseline and then see how much the before-to-after changes in the experimental group deviate from this baseline. Another variant of the randomized experiment method is regression discontinuity design, which takes advantage of what are in effect natural experiments in the region around a discrete (and exogenous) jump in the variable of interest. For a rigorous treatment of these econometric methods see Wooldridge (2002).

9. Instrumental variables attempt to deal with endogeneity by isolating and using only the exogenous component of the variable of interest.

10. The evidence that private tutoring raises achievement in the United States is overwhelming. Other studies that find that private tutoring has positive effects on SAT scores include Becker (1990) and Powers and Rock (1999). A meta-analysis study of the effects of one-on-one tutoring programs in reading for elementary students with learning difficulties shows that these programs improve student reading skills (Elbaum and others 2000).

11. Certain features of the Indonesian finding (in which one of the authors participated) may restrict its general applicability. First, the test administered was simple: the math test consisted of only 12 questions, and the dictation test consisted of a single short passage. Second, because data on student attributes and investments were limited, the tutoring variable used was a crude one: whether or not the student was currently receiving tutoring.

12. These calculations revise and update those in Dang (2007a) and are available on request.

\section{References}

Ahmed, Manzoor, Samir R. Nath, Altaf Hossain, Mahbubul Kabir, Abul Kalam, Mirja M. Shahjamal, Rosie Nilufar Yasmin, and Tata Zafar. 2005. Quality with Equity: The Primary Education Agenda. Dhaka: Campaign for Popular Education. Dhaka, Bangladesh: Campaign for Popular Education.

Assad, Ragui, and Asmaa El-Badawy. 2004. "Private and Group Tutoring in Egypt: Where Is the Gender Inequality?” Paper presented at the Economic Research Forum 11th Annual Conference: Post Conflict Reconstruction, 14-16 December, Beirut, Lebanon.

Aurini, Janice, and Scott Davies. 2004. "The Transformation of Private Tutoring: Education in a Franchise Form." Canadian Journal of Sociology 29(3):419-36.

Baker, David P., Motoko Akiba, Gerald K. LeTendre, and Alexander W. Wiseman. 2001. "Worldwide Shadow Education: Outside-School Learning, Institutional Quality of Schooling, and CrossNational Mathematics Achievement." Educational Evaluation and Policy Analysis 23(1):1-17.

Banerjee, Abhijit V., Shawn Cole, Esther Duflo, and Leigh Linden. 2007. "Remedying Education: Evidence from Two Randomized Experiments in India." Quarterly Journal of Economics 122(3): $1235-64$.

Barron, John M., Bradley T. Ewing, and Glen R. Waddell. 2000. "The Effects of High School Athletic Participation on Education and Labor Market Outcomes." Review of Economics and Statistics 82(3):409-21. 
Becker, Betsy Jane. 1990. "Coaching for the Scholastic Aptitude Test: Further Synthesis and Appraisal.” Review of Educational Research 60(3):373-417.

Becker, Gary, and H. G. Lewis. 1973. "On the Interaction between the Quantity and Quality of Children." Journal of Political Economy 81(2):S279-88.

Bedi, Arjun S., and Ashish Garg. 2000. "The Effectiveness of Private versus Public Schools: The Case of Indonesia." Journal of Development Economics 61(2):463-94.

Bishop, John H., and Ludger Wossmann. 2004. "Institutional Effects in a Simple Model of Educational Production." Education Economics 12(1):17-38.

Biswal, Bagala P.. 1999. "Private Tutoring and Public Corruption: A Cost-effective Education System for Developing Countries.” Developing Economies 37(2):222-40.

Blake, Judith. 1989. Family Size and Achievement. Berkeley: University of California Press.

Borja, Rhea R.. 2005. "Growing Niche for Tutoring Chains: Prekindergartens' Academic Prep." Education Week 25(8):10.

Bourguignon, François, and F. Halsey Rogers. (forthcoming). "Global Returns to Higher Education: Trends, Drivers, and Policy Responses.” In Justin Yifu Lin and Boris Pleskovic, eds., Regional Bank Conference on Development Economics 2007: Higher Education and Development. Washington, D.C.: World Bank.

Bray, Mark. 1999a. The Shadow Education System: Private Tutoring and Its Implications for Planners. Fundamentals of Educational Planning 61. Paris: United Nations Education, Scientific and Cultural Organization, International Institute for Educational Planning. 1999b. The Private Costs of Public Schooling: Household and Community Financing of Primary Education in Cambodia. Paris: United Nations Education, Scientific and Cultural Organization, International Institute for Educational Planning.

2003. Adverse Effects of Private Supplementary Tutoring: Dimensions, Implications and Government Responses. Paris: United Nations Education, Scientific and Cultural Organization, International Institute for Educational Planning.

2006. "Private Supplementary Tutoring: Comparative Perspectives on Patterns and Implications." Compare 36(4):515-30.

Bray, Mark, and Percy Kwok. 2003. "Demand for Private Supplementary Tutoring: Conceptual Considerations, and Socio-economic Patterns in Hong Kong." Economics of Education Review 22: 611-20.

Briggs, Derek C. 2001. "The Effect of Admissions Test Preparation: Evidence from NELS: 88." Chance 14(1):10-18.

Brunello, Giorgio, Simona Comi, and Claudio Lucifora. 2000. "The College Wage Gap in 10 European Countries: Evidence from Two Cohorts.” Working Paper 85.2000. Fondazione Eni Enrico Mattei, Milan, Italy.

Buchmann, Claudia. 1999. "The State and Schooling in Kenya: Historical Development and Current Challenges." Africa Today 46(1):95-116.

2002. "Getting Ahead in Kenya: Social Capital, Shadow Education, and Achievement." Research in Sociology of Education 13:133-59.

Budiene, Virginija, and Algirdas Zabulionis. 2006. "Lithuania.” In Silova Iveta, Virginija Budiene, and Mark Bray, eds., Education in a Hidden Marketplace: Monitoring of Private Tutoring. New York: Open Society Institute.

Chae, Sunhee, Jong-Haak Hong, and Tae Jeong Lee. 2004. "Anatomy of the Rank Structure of Korean Universities: Toward a Design of Integrated Policies for Education Reform in Korea." Paper presented at the Global Development Network Regional Research Conference, Seoul, 5-7 October. 
Chaudhury, Nazmul, Jeffrey Hammer, Michael Kremer, Karthik Muralidharan, and F. Halsey Rogers. 2006. "Missing in Action: Teacher and Health Worker Absence in Developing Countries." Journal of Economic Perspectives 20(1):91-116.

Cheo, Roland, and Euston Quah. 2005. "Mothers, Maids and Tutors: An Empirical Evaluation of Their Effect on Children's Academic Grades in Singapore.” Education Economics 13(3):269-85.

Chronicle of Higher Education. 2003. "Group in India Seeks to End For-Profit Classes." 49(36):A41.

CME (Council of Ministers of Education, Canada). 2000. Science Learning: The Canadian ContextSchool Achievement Indicators Program 1999. Toronto, Ontario.

Dang, Hai-Anh. 2007a. "The Determinants and Impacts of Private Tutoring Classes in Vietnam." Ph.D. diss., Department of Applied Economics, University of Minnesota, Minneapolis/St. Paul.

2007b. "The Determinants and Impacts of Private Tutoring Classes in Vietnam." Economics of Education Review 26(6):684-99.

Davies, Scott. 2004. "School Choice by Default? Understanding the Demand for Private Tutoring in Canada." American Journal of Education 110(3):233-55.

Dedic, Zrinka Ristic, Boris Jokix, and Lana Jurko. 2006. “Croatia.” In Iveta Silova, Virginija Budiene, and Mark Bray, eds., Education in a Hidden Marketplace: Monitoring of Private Tutoring. New York: Open Society Institute.

Dong, Alison, Batjargal Ayush, Bolormaa Testsgee, and Tumendelger Sengegodoris. 2006. "Mongolia." In Iveta Silova, Virginija Budiene, and Mark Bray, eds., Education in a Hidden Marketplace: Monitoring of Private Tutoring. New York: Open Society Institute.

Dore, Ronald. 1976. The Diploma Disease: Education, Qualification and Development. London: George Allen and Unwin.

Elbaum, Batya, Sharon Vaughn, Marie Tejero Hughes, and Sally Watson Moody. 2000. "How Effective Are One-to-One Programs in Reading for Elementary Students at Risks for Reading Failure? A Meta-Analysis of the Intervention Research.” Journal of Educational Psychology 92(4): 605-19.

Filmer, Deon, and Lant Pritchett. 1999. "The Effect of Household Wealth on Educational Attainment: Evidence from 35 Countries.” Population and Development Review 25(1):85-120.

Foondun, Raffick A. 2002. "The Issue of Private Tuition: An Analysis of the Practice in Mauritius and Selected South-East Asian Countries." International Review of Education 48(6):485-515.

Fuchs, Marek. "Tutoring Gives Pupils an Edge ... for Preschool.” New York Times, July 31, 2002, 9.

George, Cherian. "Time to Come out of the Shadows." Straits Times, April 4, 1992, 28.

Glewwe, Paul, and Seema Jayachandran. 2006. "Incentives to Teach Badly? After-School Tutoring in Developing Countries." Working paper. Department of Economics, University of Minnesota, Minneapolis/St. Paul.

Glewwe, Paul, and Michael Kremer. 2006. "School, Teachers, and Education Outcomes in Developing Countries." In Eric A. Hanushek, and Finis Welch, eds., Handbook of the Economics of Education. Amsterdam: North-Holland.

Gordon, Edward E., and Elaine H. Gordon. 2003. Literacy in America: Historic Journey and Contemporary Solutions. Westport, Conn.: Praeger.

Ha, Tran Thu, and Trudy Harpham. 2005. "Primary Education in Vietnam: Extra Classes and Outcomes." International Education Journal 6(5):626-34.

Haddon, Phoebe A., and Deborah W. Post. 2006. "Misuse and Abuse of the LSAT: Making the Case for Alternative Evaluative Efforts and a Redefinition of Merit." Saint John's Law Review 80(1): $41-105$. 
Hanushek, Eric A., and Javier A. Luque. 2003. "Efficiency and Equity in Schools around the World." Economics of Education Review 22(3):481-502.

Heckman, James J., Lance J. Lochner, and Petra E. Todd. 2006. "Earnings Functions, Rates of Return and Treatment Effects: The Mincer Equation and Beyond." In Eric A. Hanushek, and Finis Welch, eds., Handbook of the Economics of Education. Amsterdam: North Holland.

Heckman, James J., Sergio Urzua, and Edward Vytlacil. 2006. "Understanding Instrumental Variables in Models with Essential Heterogeneity." Review of Economics and Statistics 88(3): $389-432$.

Hoxby, Caroline Minter. 1994. Do Private Schools Provide Competition For Public Schools? NBER Working Paper 4978. Cambridge, Mass.: National Bureau of Economic Research.

Hrynevych, Lilya, Anna Toropova, Tymofiy Pylnyk, Leonid Sereda, and Ulyana Gerasevich. 2006. "Ukraine." In Iveta Silova, Virginija Budiene, and Mark Bray, eds., Education in a Hidden Marketplace: Monitoring of Private Tutoring. New York: Open Society Institute.

Hunt, Jennifer, and Sonia Laszlo. 2005. Bribery: Who Pays, Who Refuses, What Are the Payoffs? NBER Working Paper 11635. Cambridge, Mass.: National Bureau of Economic Research.

Ireson, Judith, and Katie Rushforth. 2005. Mapping and Evaluating Shadow Education. Economic and Social Research Council Research Project RES-000-23-0117, Institute of Education, University of London.

Jacob, Brian A., and Lars Lefgren. 2004. "Remedial Education and Student Achievement: A Regression-Discontinuity Analysis." Review of Economics and Statistics 86(1):226-44.

Kaufmann, Daniel, Aart Kray, and Massimo Mastruzzi. 2007. "Governance Matters VI: Governance Indicators for 1996-2006." (http://info.worldbank.org/governance/wgi2007/sc_country.asp).

Kenny, Diana T., and Gavin Faunce. 2004. "Effects of Academic Coaching on Elementary and Secondary School Students." Journal of Educational Research 98(2):115-26.

Kim, Gwang-Jo. 2001. "Education Policies and Reform in South Korea." In Secondary Education in Africa: Strategies for Renewal. Washington, D.C.: World Bank.

Kim, Sunwoong, and Ju-Ho Lee. 2004. "Private Tutoring and Demand for Education in South Korea." Department of Economics, University of Wisconsin, Milwaukee.

Kim, Taejong. 2005. "Shadow Education: School Quality and Demand for Tutoring in Korea." Discussion Paper 055. Interfaces for Advanced Economic Analysis, Kyoto University.

Kulpoo, Dhurumbeer, and Maya Soonarane. 2005. The SACMEQ II Project in Mauritius: A Study of the Conditions of Schooling and the Quality of Education. Harare, Zimbabwe: Southern and Eastern Africa Consortium for Monitoring Education Quality.

Kwak, Byong-Sun. 2004. "Struggle against Private Lessons in Korean Education Context." Paper presented at the 28th Annual Conference of the Pacific Circle Consortium, Hong Kong Institute of Education, 21-23 April.

Lavy, Victor, and Analia Schlosser. 2005. "Targeted Remedial Education for Underperforming Teenagers: Costs and Benefits." Journal of Labor Economics 23(4):839-74.

Lee, Jong-Tae, Yang-Boon Kim, and Cho-Hee Yoon. 2004. "The Effects of Pre-Class Tutoring on Student Achievement: Challenges and Implications for Public Education in Korea." KEDI Journal of Educational Policy 1(1):25-42.

Lee, Sanghoon Conan. 2007. "The Timing of Signaling: To Study in High School or in College?" International Economic Review 48(3):785-807.

LeTendre, Gerald. 1994. "Distribution Tables and Private Tests: The Failure of Middle School Reform in Japan." International Journal of Educational Reform 3(2):126-36. 
Lipscomb, Stephen. 2007. "Secondary School Extracurricular Involvement and Academic Achievement: A Fixed-Effects Approach." Economics of Education Review 26(4):463-72.

Machingaidze, Thomas, Patrick Pfukani, and Sibangani Shumba. 1998. The Quality of Education: Some Policy Suggestions Based on a Survey of Schools in Zimbabwe. SACMEQ Policy Research Report. Paris: United Nations Education, Scientific and Cultural Organization, International Institute for Educational Planning.

Matiashvili, Anna, and Nino Kutateladze. 2006. “Georgia.” In Iveta Silova, Virginija Budiene, and Mark Bray, eds., Education in a Hidden Marketplace: Monitoring of Private Tutoring. New York: Open Society Institute.

Mingat, Alain, and Jee-Peng Tan. 2003. "On the Mechanics of Progress in Primary Education." Economics of Education Review 22(5):455-67.

Mischo, Christoph, and Haag Ludwig. (2002) "Expansion and Effectiveness of Private Tutoring." European Journal of Psychology of Education 17(3):263-73.

NCES (National Center for Education Statistics). 1996. Pursuing Excellence: A Study of U.S. Eighth-Grade Mathematics and Science Teaching, Learning, Curriculum, and Achievement in International Context. Washington, D.C.: U.S. Department of Education, National Center for Education Statistics.

Newhouse, David, and Kathleen Beegle. 2006. "The Effect of School Type on Academic Achievement: Evidence from Indonesia." Journal of Human Resources 41(3):529-57.

Ono, Hiroshi. 2007. "Does Examination Hell Pay Off? A Cost-Benefit Analysis of 'Ronin' and College Education in Japan." Economics of Education Review 26(3):271-84.

Onsomu, Eldah, Juliana Nzomo, and Charles Obiero. 2005. The SACMEQ II Project in Kenya: A Study of the Conditions of Schooling and the Quality of Education. Harare: Southern and Eastern Africa Consortium for Monitoring Education Quality.

Paviot, Laura, Nina Heinsohn, and Julia Korkman. 2008. "Extra Tuition in Southern and Eastern Africa: Coverage, Growth, and Linkages with Pupil Achievement.” International Journal of Educational Development 28(2):149-60.

Powers, Donald E., and Donald A. Rock. 1999. "Effects of Coaching on SAT I: Reasoning Test Scores." Journal of Educational Measurement 36(2):93-118.

Psacharopoulous, George, and George Papakonstantinou. 2005. "The Real University Cost in a 'Free' Higher Education Country." Economics of Education Review 24(1):103-08.

Psacharopoulos, George, and Harry Anthony Patrinos. 2004. "Returns to Investment in Education: A Further Update." Education Economics 12(2):111-34.

Rogers, F. Halsey. 1996. "Four Pass, Five Fail: Multiple Ability Signals and Cross-Country Differences in Educational Effort." Ph.D. diss., Department of Economics, University of California, Berkeley.

Rohlen, Thomas P. 1980. "The Juku Phenomenon: An Exploratory Essay.” Journal of Japanese Studies 6(2):207-42.

Rouse, Cecilia Elena. 1998. "Private School Vouchers and Student Achievement: An Evaluation of the Milwaukee Parental Choice Program." Quarterly Journal of Economics 113(2):553-602.

Russell, Nancy Ukai. 1997. "Lessons from Japanese Cram Schools." In W.K. Cummings, and P. Altbach,eds., The Challenge of Eastern-Asian Education: Lessons for America. Albany: State University of New York Press.

Silova, Iveta, and Mark Bray. 2006a. "The Hidden Marketplace: Private Tutoring in Former Socialist Countries." In Iveta Silova, Virginija Budiene, and Mark Bray, eds., Education in a Hidden Marketplace: Monitoring of Private Tutoring. New York: Open Society Institute.

2006b. "Implications for Policy and Practice." In Iveta Silova, Virginija Budiene, and Mark Bray, eds., Education in a Hidden Marketplace: Monitoring of Private Tutoring. New York: Open Society Institute. 
Silova, Iveta, and Elmina Kazimzade. 2006. "Azerbaijan.” In Iveta Silova, Virginija Budiene, and Mark Bray, eds., Education in a Hidden Marketplace: Monitoring of Private Tutoring. New York: Open Society Institute.

Spence, M. 1973. “Job Market Signaling.” Quarterly Journal of Economics 87(3):355-74.

Stevenson, David Lee, and David Baker. 1992. "Shadow Education and Allocation in Formal Schooling: Transition to University in Japan." American Journal of Sociology 97(6): 1639-57.

Stylianou, Vasso, Andreas Savva Maria Vraka, and Andreas Serghiou. 2003. "Information and Communication Technology: First-Aid to the Private Tutoring Problem?" School of Sciences and Engineering, Intercollege, Nicosia, Cyprus. [http://cblis.utc.sk/cblis-cd-old/2003/2.PartA/Papers/ ICT/Stylianou.pdf\#search='Information\%20and\%20Communication\%20Technology\%3 A\% 20FirstAid\%20to\%20the\%20Private\%20Tutoring\%20Problem].

Suliman, El Daw A., and Safaa E. El-Kogali. 2002. "Why Are Children out of School? Factors Affecting Children's Education in Egypt." Paper presented at the Economic Research Forum, Ninth Annual Conference, 26-28 October, Al-Sharjah, United Arab Emirates.

Suryadarma, Daniel, Asep Suryahadi., Sudarno Sumarto, and F. Halsey Rogers. 2006. "Improving Student Performance in Public Primary Schools in Developing Countries: Evidence from Indonesia." Education Economics 14(4):401-29.

Tansel, Aysit. 1997. "Schooling Attainment, Parental Education, and Gender in Côte d'Ivoire and Ghana." Economic Development and Cultural Change 45(4):825-56.

1998. "Determinants of School Attainment of Boys and Girls in Turkey." Economic Growth Center Discussion Paper 789, Yale University, New Haven, Conn.

Tansel, Aysit, and Fatma Bircan. 2006. "Demand for Education in Turkey: A Tobit Analysis of Private Tutoring Expenditures." Economics of Education Review 25(3):303-13.

UNESCO (United Nations Economic, Scientific, and Cultural Organization). 2000. The EFA 2000 Assessment: Country Reports-Romania. Paris. (www2.unesco.org/wef/countryreports/romania/ contents.html\#cont).

Wooldridge, Jeffrey M. 2002. Econometric Analysis of Cross Section and Panel Data. Cambridge, Mass.: MIT Press.

World Bank. 2003. World Development Report 2004: Making Services Work for Poor People. Washington, D.C.: Oxford University Press for the World Bank. 